\title{
Simulation of the Stock of Electric Appliances and Calculation of Standby Losses for Latvia
}

\author{
Evita Gara, Institute of Energy Systems and Environment, Riga Technical University, Claudio Rochas, Institute of \\ Energy Systems and Environment, Riga Technical University
}

\begin{abstract}
Standby losses in households are discussed in this paper. As there was no information on the total volume of standby losses in Latvia, the objective of the study was to calculate: the percentage from the household total electricity bill that goes to standby losses; what are the total costs for these losses; and how much $\mathrm{CO}_{2}$ is produced to generate the amount of electricity that is needed to cover these standby losses. All calculations were conducted for one and for all households in Latvia and the results of one household were compared with an average European household. Finally, the savings potential that can be obtained implementing the Eco-design Directive and other political instruments was examined.
\end{abstract}

Keywords - standby losses, average household, standby measurements, standby electricity consumption.

\section{INTRODUCTION}

Acid rain, global warming, ozone depletion, the average increase in temperature, water level rises - these are only some global problems. Every year we can add a new problem. Energy consumption in standby mode is responsible for $\mathrm{CO}_{2}$ emission production and thus can be named as one of the global problems with a significant environmental impact.

The fulfillment of end-user needs and expectations increase electricity demand year by year. Electricity is necessary for operation of both simple and complex systems and equipment, but the user pays for the electricity, which he/she does not even consume directly when appliances are left in a standby mode. Equipment that is not being used and does not fulfil its primary function is in standby or off mode and the electricity consumed in these modes has to be paid by the consumer. Also, in order to produce this energy, carbon dioxide $\left(\mathrm{CO}_{2}\right)$ is emitted in the atmosphere. One issue is to be able to prevent or to limit the impact of a reduction in other problems. EU Ecodesign Directive states that the energy consumption in standby and off modes must be reduced [1].

Electrical equipment and appliances can be operated in four modes:

- Active mode;

- Active standby mode;

- Passive standby mode;

- Off mode.

Standby power consumption is the power used by appliances when they are switched off or are not performing their primary function. For example, a device will continue to draw power after the user switches it off with the remote control. Standby power consumption however is not restricted to products with remote controls. All products with an external power supply also consume power when idle as do most household appliances and computer products.

Commission Regulation (EC) 1275/2008, 17 December 2008, implementing Directive 2005/32/EC of the European Parliament and of the Council with regard to eco-design requirements for standby and off mode electric power consumption of electrical and electronic household and office equipment [1]. The determined energy consumption values set in the Directive are shown in Fig.1.

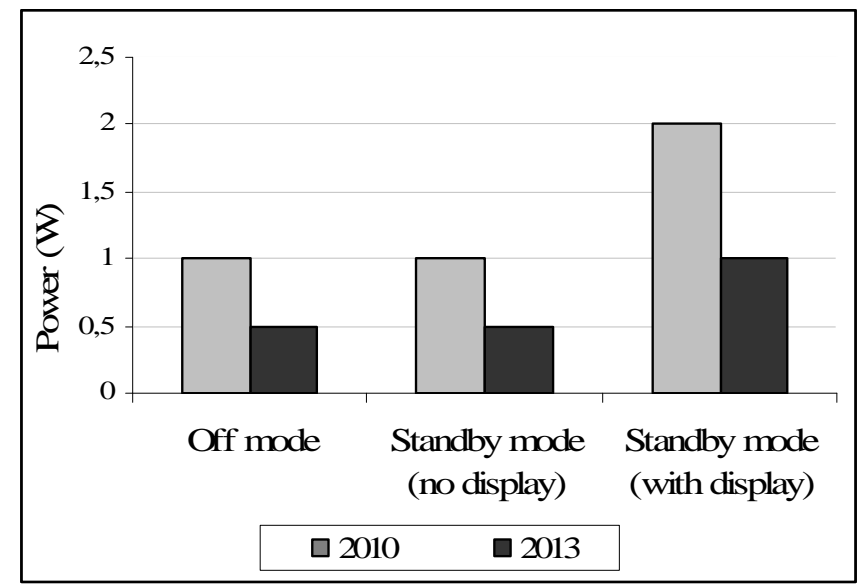

Fig.1. Requirements of eco-design requirements [5].

Figure 1 shows that in 2010 power consumption of equipment in any off-mode condition shall not exceed $1 \mathrm{~W}$. The power consumption of equipment in any condition providing only a reactivation function, or providing only a reactivation function and a mere indication of enabled reactivation function, shall not exceed $1 \mathrm{~W}$. The power consumption of equipment in any condition providing only information or status display, or providing only a combination of reactivation function and information or status display, shall not exceed $2 \mathrm{~W}$.

In 2013, power consumption of equipment in any off-mode condition shall not exceed $0.5 \mathrm{~W}$. The power consumption of equipment in any condition providing only a reactivation function, or providing only a reactivation function and a mere indication of enabled reactivation function, shall not exceed $0.5 \mathrm{~W}$. The power consumption of equipment in any condition providing only information or status display, or providing only 
a combination of reactivation function and information or status display shall not exceed $1 \mathrm{~W}$.

So far there were no studies performed related to standby and off mode energy consumption in Latvia. Still, it was important to identify the effect that standby mode had on the total household electricity consumption, cost, and total $\mathrm{CO}_{2}$ emissions emitted by energy production plants.

The main objective was to determine how large is standby mode power consumption, electric power consumption and carbon dioxide $\left(\mathrm{CO}_{2}\right)$ emissions that are emitted to produce required amount of electricity for Latvian households, increasing the global warming effect from electrical equipment and appliances. The household sector was chosen because it was the largest final consumer of energy.

To determine the stand-by losses in Latvia, a model of an average household was used considering proportions of the existing facilities, power and electricity consumption, costs and $\mathrm{CO}_{2}$ emissions. Potential that can be achieved by following the European Union to adopt Eco-design Directive in terms of standby consumption in Latvian households was calculated. Also, results that had never been obtained before were delivered as the result of the modelling.

\section{II.RESEARCH APPROACH AND METHODS}

The International Energy Agency stated that the world's energy consumption in standby mode ranges from 200TWh to 400TWh per year, or equals to $1 \%$ of total $\mathrm{CO}_{2}$ emissions in the air, but these are only approximate figures, therefore, an initial objective was set to determine how large is the Latvian domestic stand-by consumption. Until now no similar studies have been carried out [2].

Standby power can be significantly reduced by up to $90 \%$ of the total standby power consumption while maintaining all the key functions required for an appliance to operate in accordance with requirements.

\section{A. Measurements}

Wattman HPM 100A (Figure 2) meters were used for power consumption and standby power measurements. Wattman (HPM-100A) is consumption / standby power analyzer and a practical and economical handheld wattmeter. This instrument enables measurement of the power consumption of home appliances and business equipment with no greater than a $9 \mathrm{~mW} \sim 3.75 \mathrm{~kW}$ power consumption, in a Plug\& Play way, thus allowing easy and simple operation by any user. It also enables easy conversion of electric power usage data into an electric charge and possibility to define $\mathrm{CO}_{2}$ emissions values.

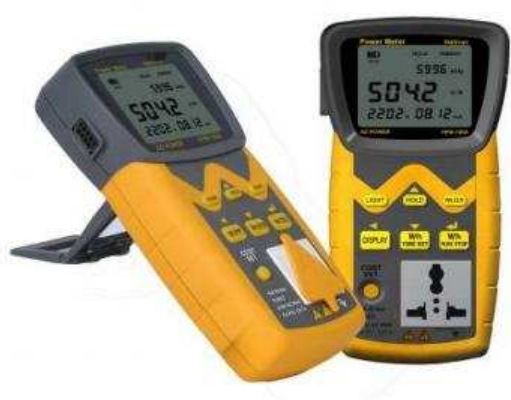

Fig.2. Wattman HPM 100.

Using this equipment measures were carried out in stores selling electrical appliances in order to determine which of measured appliances exceeded eco-design requirements.

\section{B. Algorithm}

Algorithm (Figure 3) in steps describes the order in which electricity consumption for specified electrical appliances and equipment is defined in standby mode in Latvian households.

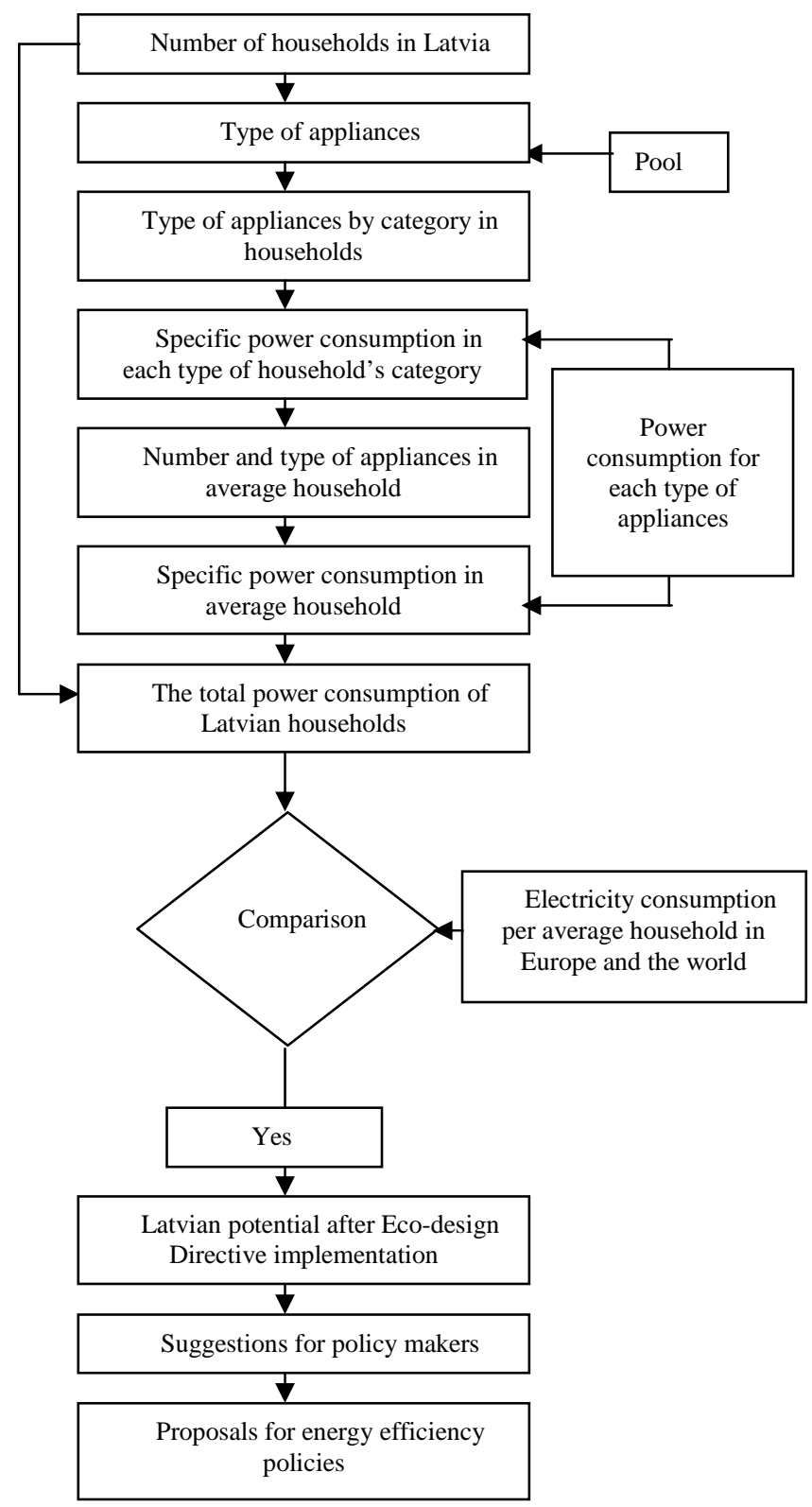


determining the potential of what can be reduced by reducing the total power consumption, cost and global $\mathrm{CO}_{2}$ emissions.

Given the existing potential of the Directive was also

Fig.3. Algorithm for definition of energy losses in standby mode [5].

Data on Latvian households for time period from year 2002 to 2008 were obtained from the Central Statistical Bureau (CSB) database.

In order to assess the existing situation in an average Latvian household, a survey was carried out. The respondents were asked to select the type of dwelling where they live and the number of different equipment that can be found in their homes.

The survey results determined what equipment is most commonly found in each type of housing, whether it is a flat or private house, since each housing type has its own trends as far as the proportion of existing facilities, their type and quantity.

In order to determine what the total power consumption of appliances in standby mode is for each type of dwelling, the results of general studies were used to show how much each unit consumed in standby mode, how many hours per year the equipment is operated in that mode, the total power consumption, and $\mathrm{kWh}$ per year by each of the appliances are consumed while operated in this mode.

After analyzing the statements made about the existing types of equipment for each type of housing, the total equipment capacity (W) and total electricity consumption ( $\mathrm{kWh} /$ year) were defined. Additionally, costs related to the consumed energy (Ls) that the consumer is to cover to the electricity supplier were defined, as well as $\mathrm{CO}_{2}$ emissions $(\mathrm{kg})$ that are emitted in order to produce the given electricity volume.

Using the results that were used to model the average household in Latvia it was assumed that number of each type of housing in Latvia can fluctuate within time. Knowing the total number of households the approach was the chosen to model the number and type of equipment in an average household. In the result, total power consumption in an average household and for Latvian households together was obtained. So far, there are various projects and developed programs being implemented in Europe and other world countries on reduction of standby power consumption in order to achieve that the standby power consumption of the all appliances is limited within $5-10 \%$ [3] of the total household energy consumption. Comparing and analyzing the results some differences were found, although this difference may appear due to the fact that appliances available on each country's market differ. For example, equipment, which can be found in the developed countries, might be not found lower in developing countries and vice versa, thus each country's average electricity consumption in standby mode can be different.

In determining the average household of the equipment on the type and number of existing plants was calculated on the reduced power consumption when the plant capacity, which exceeds by 2013 the application of eco-design requirements would be reduced to this Directive, the values, thereby suggested to policy makers and energy policy makers as to ensure that Latvia comply by 2013 of the Directive.

\section{III.RESULTS}

During the project implementation in Latvia standby and off mode energy consumption measurements were performed for 31 categories of equipment in cooperation with PTA household appliance store in Riga. The results of the preformed measurements are shown in figure 4.

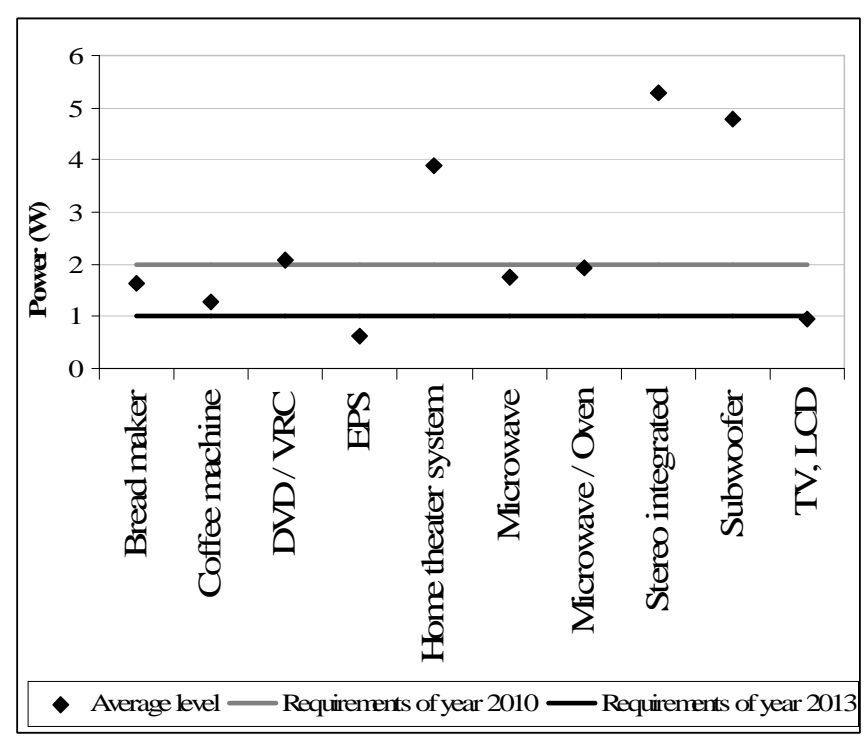

Fig.4. Measurement results in standby mode.

The figure above shows measurement results for electronic and energy consuming equipment in standby mode. Three categories of equipment exceed requirements for energy consumption level introduced in year 2010. Though, only half of all measured categories will comply in terms of energy consumption in standby with the requirements to be introduced in year 2013. This means that producers of equipment will have to introduce special measures to improve energy efficiency of standby mode until year 2013.

Results of the measurements are summarized in the figure 5 where all equipment that does not comply with requirements for energy consumption in both modes of both legislative stages is shown. 


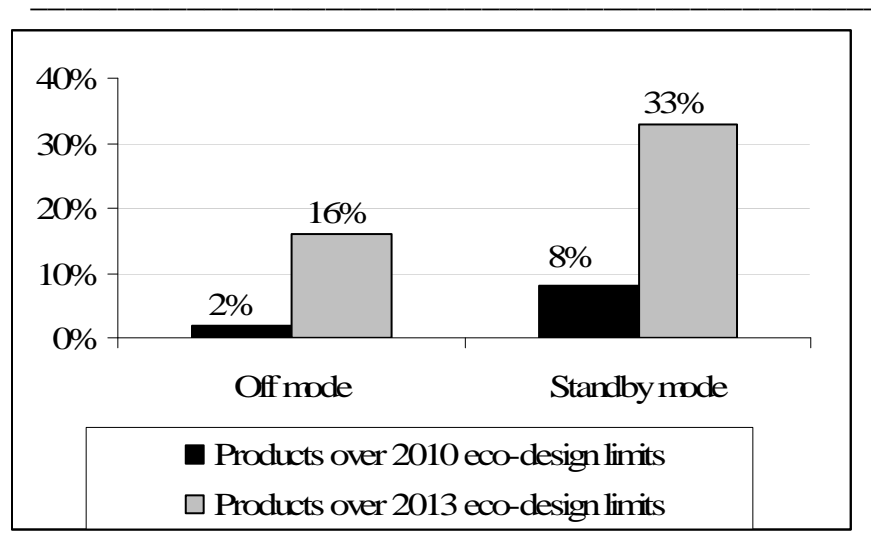

Fig.5. Compatibility of the appliances' low-power consumption with the directive requirements.

Summary of the measured data shows that $98 \%$ of the measured in off-mode devices confirms with the requirements introduced in year 2020, and $92 \%$ - to the requirements to be introduced in year 2013. In standby mode measured equipment meets the requirements of 2010 for $94 \%$, and requirements of 2013 - for $67 \%$. This means that producers will have to work hard to provide necessary off-mode values for $10 \%$ of all available equipment and for standby values for $49 \%$ of equipment available for sale.

The effort to gather sales/stock data, energy consumption / watt and standard hours of use in low power modes is still in progress. Present gathered information on consumption for 44 products is presented in the Table 1. These are preliminary findings that are to be consolidated with comments further analysis. From these first results, some products in the present list represent a minor contribution to the total energy consumption and are not to be considered in priority.

TABLE 1

EXTENDED LIST OF PRODUCTS FROM PREVIOUS STUDIES // VOLUMES SALES AND OR ESTIMATED STOCK [4]

\begin{tabular}{|l|c|l|l|}
\hline Product name & $\begin{array}{l}\text { Standby } \\
\text { power } \\
{[\mathbf{W}]}\end{array}$ & $\begin{array}{l}\text { Consumption } \\
\text { hours } \\
{[\mathbf{h} / \mathbf{d}]}\end{array}$ & $\begin{array}{l}\text { Energy } \\
\text { Consumption } \\
\text { per one unit } \\
{[\mathbf{K W h} / \mathbf{y r}]}\end{array}$ \\
\hline Coffee maker & 1.52 & 0.26 & 0.14 \\
\hline Microwave & 2.40 & 23.79 & 20.84 \\
\hline Oven & 3.00 & 23.70 & 25.95 \\
\hline Clothes Washer & 5.70 & 3.00 & 6.24 \\
\hline Cooktops & 1.13 & 19.00 & 7.84 \\
\hline Dishwasher & 0.60 & 2.41 & 0.53 \\
\hline Electric toothbrush & 1.40 & 2.10 & 1.07 \\
\hline Hair dryer & 8.62 & $*$ & $*$ \\
\hline Amplifier & 33.99 & $*$ & $*$ \\
\hline CD Player & 4.80 & 12.00 & 21.02 \\
\hline DVD & 2.07 & 15.60 & 11.79 \\
\hline DVD players & 7.54 & 15.58 & 42.88 \\
\hline DVD recorders & 18.30 & 15.16 & 101.26 \\
\hline $\begin{array}{l}\text { Home theatre } \\
\text { system }\end{array}$ & 0.70 & 23.00 & 5.88 \\
\hline
\end{tabular}

\begin{tabular}{|c|c|c|c|}
\hline Radio & 1.50 & 1.00 & 0.55 \\
\hline $\begin{array}{l}\text { Stereo } \\
\text { integrated }\end{array}$ & 8.00 & 17.10 & 49.93 \\
\hline Subwoofer & 6.40 & 16.06 & 37.52 \\
\hline Digital camera & 6.00 & 0.16 & 0.35 \\
\hline Projector & 6.97 & 12.11 & 30.81 \\
\hline $\mathrm{TV}$ & 5.80 & 12.00 & 25.40 \\
\hline TV,CRT & 3.10 & 12.11 & 13.70 \\
\hline TV,LCD & 3.10 & 12.11 & 13.70 \\
\hline TV,PLASMA & 0.40 & 12.11 & 1.77 \\
\hline Set-Top box & 10.70 & 20.00 & 78.11 \\
\hline VCR & 2.00 & 15.16 & 11.07 \\
\hline $\begin{array}{l}\text { Computer } \\
\text { monitor }\end{array}$ & 4.50 & 9.60 & 15.77 \\
\hline Desktop & 4.00 & 9.20 & 13.43 \\
\hline Notebook & 3.00 & 9.00 & 9.86 \\
\hline PDA & 1.00 & 6.65 & 2.43 \\
\hline Smart Phone & 2.00 & 23.59 & 17.22 \\
\hline $\begin{array}{l}\text { Speaker } \\
\text { (computer) }\end{array}$ & 3.60 & 2.40 & 3.15 \\
\hline Copier & 10.70 & 0.07 & 0.27 \\
\hline Fax machines & 5.90 & 23.10 & 49.75 \\
\hline Inkjet printer & 6.00 & 1.90 & 4.16 \\
\hline Product name & $\begin{array}{l}\text { Standby } \\
\text { power } \\
{[W]}\end{array}$ & $\begin{array}{l}\text { Consumption } \\
\text { hours } \\
{[\text { h/d] }}\end{array}$ & $\begin{array}{l}\text { Energy } \\
\text { Consumption } \\
\text { per one unit } \\
{[\mathrm{KWh} / \mathrm{yr}]} \\
\end{array}$ \\
\hline Laser printer & 20.00 & 1.90 & 13.87 \\
\hline Scanner & $*$ & 16.19 & $*$ \\
\hline Dial-up modem & $*$ & 2.60 & $*$ \\
\hline $\begin{array}{l}\text { Modems } \\
\text { Routers }\end{array}$ & 5.00 & 20.00 & 36.50 \\
\hline $\begin{array}{l}\text { Wireless access } \\
\text { point }\end{array}$ & 4.70 & $*$ & $*$ \\
\hline $\begin{array}{l}\text { Phone } \\
\text { Cordless }\end{array}$ & 2.40 & 22.60 & 19.80 \\
\hline $\begin{array}{l}\text { Home security } \\
\text { system }\end{array}$ & 2.26 & $*$ & $*$ \\
\hline $\begin{array}{l}\text { Sensor } \\
\text { (Light) }\end{array}$ & 1.00 & 23.00 & 8.40 \\
\hline $\begin{array}{l}\text { EPS(mobile } \\
\text { phone) }\end{array}$ & $*$ & 1.40 & $*$ \\
\hline $\begin{array}{l}\text { Lighting, Lamp/ } \\
\text { transformers }\end{array}$ & $*$ & 0.50 & $*$ \\
\hline
\end{tabular}

* - Power, consumption hours and power consumption values are unknown; these values have not been defined and calculated till now.

\section{A. Pool results}

In order to clarify and model the average household of electrical and electronic equipment and devices a survey was made. 214 Latvian and Russian speaking respondents participated in the survey. Figure 6 shows housing allocation according to the percentage of the respondents. 


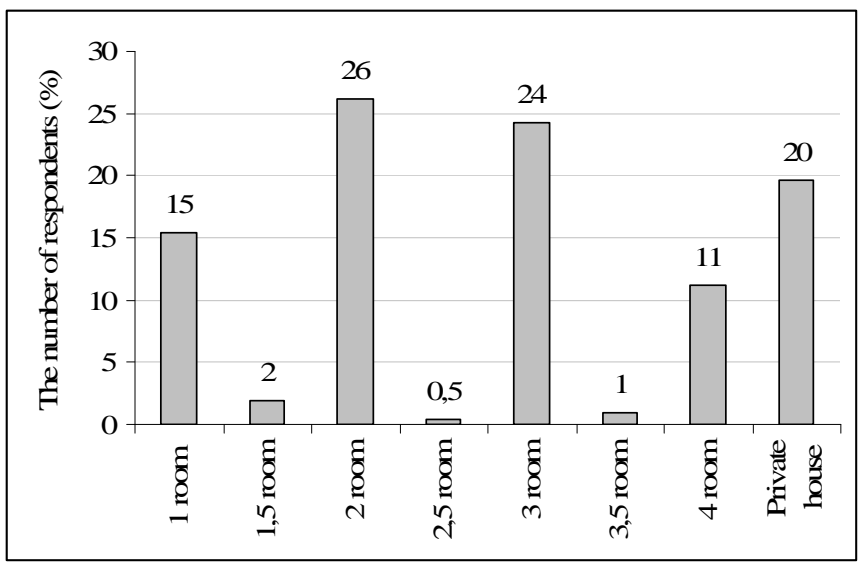

Fig.6. Respondents' housing allocation.

As shown in this figure, the half - 50\%, t.i. 107 of the respondents live in two-room and three-room apartments, while almost a quarter - $20 \%$, t.i. 42 of the respondents live in private houses. The other $30 \%$ of the respondents live in one room, one and a half rooms, two and a half room, three and a half and four and more room apartments.

\section{B. The average household in Latvia}

The obtained survey results were used to model an average household in Latvia. Since three-quarters of the respondents live in two-room, three-room apartments and private houses, most popular for those respondents equipment was taken into account.

Equipment that is found most often in two-room, threeroom apartments and in private house and that is normally left in standby was used to make the model (Table 2). In case of the average household it was assumed that there are 14 main product groups in the household and their total power output is $38 \mathrm{~W}$, which results in total power consumption of $150 \mathrm{kWh} /$ year or of $11 \mathrm{Ls}$ to be paid to the electricity supplier. For the electricity producers this amount of electricity equals to $60 \mathrm{~kg}$ of $\mathrm{CO}_{2}$ emitted in the atmosphere.

TABLE 2

EQUIPMENT TYPES AND CONSUMPTIONLEVELS IN AN AVERAGE HOUSEHOLD

\begin{tabular}{|l|l|l|l|l|l|}
\hline $\begin{array}{l}\text { Product } \\
\text { name }\end{array}$ & $\begin{array}{l}\text { Standby } \\
\text { power } \\
{[\mathbf{W}]}\end{array}$ & $\begin{array}{l}\text { Con- } \\
\text { sumption } \\
\text { hours } \\
{[\mathbf{h} / \mathbf{d}]}\end{array}$ & $\begin{array}{l}\text { Energy } \\
\text { Con- } \\
\text { sumption } \\
\text { per one } \\
\text { unit } \\
{[\mathbf{k W h} / \mathbf{y r}]}\end{array}$ & $\begin{array}{l}\text { Costs } \\
\text { per } \\
\text { one } \\
\text { unit } \\
{[\mathbf{L s}]}\end{array}$ & $\begin{array}{l}\mathbf{C O}_{2} \\
\text { emi- } \\
\text { ssions } \\
\text { per one } \\
\text { unit } \\
{[\mathbf{k g} / \mathbf{y r}]}\end{array}$ \\
\hline Microwave & 2.40 & 23.79 & 20.84 & 1.55 & 8.27 \\
\hline Oven & 3.00 & 23.70 & 25.95 & 1.93 & 10.30 \\
\hline Radio & 1.50 & 1.00 & 0.55 & 0.04 & 0.22 \\
\hline $\begin{array}{l}\text { Radio }+ \\
\text { CD }\end{array}$ & 4.80 & 1.00 & 1.75 & 0.13 & 0.70 \\
\hline TV,LCD & 3.10 & 12.11 & 13.70 & 1.02 & 5.44 \\
\hline TV,CRT & 3.10 & 12.11 & 13.70 & 1.02 & 5.44 \\
\hline
\end{tabular}

\begin{tabular}{|l|l|l|l|l|l|}
\hline DVD & 2.07 & 15.60 & 11.79 & 0.88 & 4.68 \\
\hline VCR & 2.00 & 15.16 & 11.07 & 0.82 & 4.39 \\
\hline $\begin{array}{l}\text { Home } \\
\text { security } \\
\text { system }\end{array}$ & 0.70 & 23.00 & 5.88 & 0.44 & 2.33 \\
\hline Notebook & 3.00 & 9.00 & 9.86 & 0.73 & 3.91 \\
\hline $\begin{array}{l}\text { Computer } \\
\text { monitor }\end{array}$ & 4.50 & 9.60 & 15.77 & 1.17 & 6.26 \\
\hline Desktop & 4.00 & 9.20 & 13.43 & 1.00 & 5.33 \\
\hline $\begin{array}{l}\text { Speaker - } \\
\text { computer }\end{array}$ & 3.60 & 2.40 & 3.15 & 0.23 & 1.25 \\
\hline Speaker & 0.42 & 16.10 & 2.47 & 0.18 & 0.98 \\
\hline Total: & $\mathbf{3 8}$ & $\mathbf{1 7 4}$ & $\mathbf{1 5 0}$ & $\mathbf{1 1}$ & $\mathbf{6 0}$ \\
\hline
\end{tabular}

\section{Calculation example}

By knowing the power consumption per average household and number of households in Latvia it is possible to calculate total power consumption in Latvian households:

$$
\mathrm{A}=\mathrm{B} * \mathrm{C} / 1000000
$$

where

A - Total power consumption in Latvian households, GWh;

B - Total power consumption per average household, kWh;

C - Number of households in Latvia.

$$
\mathrm{A}=150 * 1042158 / 1000000=156 \mathrm{GWh}
$$

To calculate the cost there is tariff and total power consumption needed:

$$
\mathrm{D}=\mathrm{A} * \mathrm{E}
$$

where

D - Total cost of the electricity what consumes appliances in standby mode, Ls;

E - Electricity tariff - 0, 0743, Ls / kWh, or 74 300, Ls / GWh.

$$
\mathrm{D}=156 * 74300=11590800 \mathrm{Ls}
$$

In order to calculate the $\mathrm{CO}_{2}$ emissions there are total power consumption and emission factor needed:

$$
\mathrm{F}=\mathrm{A} * \mathrm{G}
$$

where

$\mathrm{F}$ - Total $\mathrm{CO}_{2}$ emissions produced, tons;

$\mathrm{G}-\mathrm{CO}_{2}$ emission factor for electricity generation $-0,397 \mathrm{~kg} /$ $\mathrm{kWh}$, or 397 tons / GWh

$$
\mathrm{D}=156 * 397=61932 \text { tons. }
$$

There were 1018096 households in Latvia in year 2006 (central statistical data), which together accounted for 1727 
979MWh of energy consumption, or $1727 \mathrm{GWh}$ of electricity consumed per year (central statistical data), which is $24 \%$ of the total Latvian electricity consumption. In standby mode the total electricity consumption amounted to an average of $153 \mathrm{GWh}$, which is $8.8 \%$ of Latvian households and $2 \%$ of the total electricity consumption in Latvian in 2006.

The average consumption per household was calculated from the same household average electricity consumption was about $1697 \mathrm{kWh}$, taking into account that the average households total electricity consumption in standby mode up an average of $150 \mathrm{kWh}$, then standby mode from the total household electricity consumption is $8.8 \%$.

Comparing the results with other countries in Europe and the average power consumption in standby mode, it can be concluded that in Latvia there is a similar situation as in other countries.

\section{Saving potential}

Based on the Eco-design Directive requirements Latvian potential (Table 3) was calculated.

TABLE 3

STANDBY MODE REDUCED POTENTIAL IN HOUSEHOLDS

\begin{tabular}{|c|c|c|c|c|}
\hline & $\begin{array}{l}\text { Total } \\
\text { standby } \\
\text { power } \\
{[W]}\end{array}$ & $\begin{array}{l}\text { Total } \\
\text { electricity } \\
\text { consumption } \\
{[\mathbf{k W h} / \mathbf{y r}]}\end{array}$ & $\begin{array}{l}\text { Total } \\
\text { costs } \\
\text { [Ls/yr] }\end{array}$ & $\begin{array}{l}\text { Total } \\
\mathrm{CO}_{2} \\
\text { emissions } \\
{[\mathrm{kg} / \mathrm{yr}]}\end{array}$ \\
\hline $\begin{array}{l}\text { Before Eco- } \\
\text { design } \\
\text { Directive } \\
\text { implementation }\end{array}$ & 38 & 150 & 11 & 60 \\
\hline $\begin{array}{l}\text { After Eco- } \\
\text { design } \\
\text { Directive } \\
\text { implementation }\end{array}$ & 10 & 46 & 3 & 18 \\
\hline $\begin{array}{l}\text { Stand-by } \\
\text { potential per } \\
\text { household }\end{array}$ & 28 & 104 & 8 & 42 \\
\hline \multicolumn{5}{|c|}{ Decrease [\%] } \\
\hline \multirow[t]{2}{*}{$\begin{array}{l}\text { The percentage } \\
\text { decrease }\end{array}$} & 74 & 69 & 73 & 70 \\
\hline & $\begin{array}{l}\text { Total } \\
\text { standby } \\
\text { power } \\
{[\mathrm{MW}]}\end{array}$ & $\begin{array}{l}\text { Total } \\
\text { electricity } \\
\text { consumption } \\
{[\mathbf{G W h} / \mathbf{y r}]}\end{array}$ & $\begin{array}{l}\text { Total } \\
\text { costs } \\
{[\mathrm{Ls} / \mathrm{yr}]}\end{array}$ & $\begin{array}{l}\text { Total } \\
\mathrm{CO}_{2} \\
\text { emissions } \\
{[\text { ton/yr] }}\end{array}$ \\
\hline $\begin{array}{l}\text { Standby } \\
\text { consumption in } \\
\text { Latvian } \\
\text { households in } \\
2008\end{array}$ & 40 & 156 & 11590800 & 61932 \\
\hline $\begin{array}{l}\text { Standby mode } \\
\text { saving potential }\end{array}$ & 30 & 108 & 8461284 & 43352 \\
\hline
\end{tabular}

The following table shows results of potential what can be achieved if Eco-design Directive requirements were met. Significantly effect of the standby power electricity consumption, as well as related costs and $\mathrm{CO}_{2}$ emission reductions is significant. As shown, the total standby power is reduced by $74 \%$, reducing electricity consumption by $69 \%$, thereby standby power consumption from total household electricity consumption decreases from $8.8 \%$ till $2.7 \%$. The total costs will be reduced by $73 \%$ and $\mathrm{CO}_{2}$ emissions, which are emitted in atmosphere by producing this electricity amount, will be cut by $70 \%$. As a result, the potential performance of Latvian households is $108 \mathrm{GWh}$ of electricity per year, saving $8461284 \mathrm{Ls}$ and 43352 tons of $\mathrm{CO}_{2}$ emission.

\section{IV.CONCLUSIONS}

International Energy Agency has confirmed that standby power is responsible for roughly $1 \%$ of global carbon dioxide emissions with consumption estimated to be between 200TWh and 400TWh per year. That level of emissions is almost equal to Australia's total emissions and is not far behind the world's airline industry or the international ICT industry which each contribute around $2 \%$. Standby power needs to be considered as a significant contributor to global warming.

A typical home in an industrialized country often contains at least 20 devices constantly drawing standby power. Individually the energy consumption in standby mode for each product may be small; however, the sheer number of appliances continually drawing power quickly adds up to 5$10 \%$ of total electricity used by most homes, and $8.8 \%$ in Latvia

For the first time in Latvia a methodology on how determinate the standby losses have been developed. Using this methodology it was determined that the standby power consumption of Latvian households is $156 \mathrm{GWh}$ per year and it annually produces $\sim 62000$ tons of $\mathrm{CO}_{2}$. There would be no need for $40 \mathrm{MW}$ high power stations to generate electricity for standby mode consumption.

It is possible to reduce total standby power, electricity consumption, costs and $\mathrm{CO}_{2}$ emissions from $69 \%$ to $74 \%$, it means that saving potential is large enough to ensure that Ecodesign Directive requirements are fulfilled.

\section{ACKNOWLEDGMENTS}

The study presented in this paper was possible due to the project "SELINA - Standby and Off-Mode Energy Losses in New Appliances". (Nr. IEE-07-563 / SI2.499206) witch was financed by Intelligent Energy Europe Programme.

\section{REFERENCES}

1. Commission Regulation (EC) No. $1275 / 2008$ // Official Journal of the European Union. - No. L 339/45. (18 December 2008).

2. Energy Efficiency Branch, Department of the Environment, Water, Heritage and the Arts. Standby power store survey 2008-09, Interim Report, October 2008, No. 2008/12, Victoria, Australia.

3. International Energy Agency. Saving electricity in a hurry. - France: Jouve, 2005. - 127 pages.

4. Da Silva D., Cho Y-s., Rivière P. Field measurement and awareness survey in shops and stores of new equipment. Draft report Methodology for field measurements. 29 April 2009.

5. Gara, E. Simulation of the stock of electric appliances and calculation of standby losses for Latvia. Master thesis. Riga: Riga Technical University, 2010. $86 \mathrm{p}$. 
Evita Gara, Mg.sc.

Institute of Energy Systems and Environment, Riga Technical University

Address: Kronvalda blvd. 1, LV 1010, Riga, Latvia

Phone: + 37128608728

e-mail: evita.gara@ rtu.lv
Claudio Rochas, Dr.sc.ing.

Institute of Environment and Energy Systems, Riga Technical University

Address: Kronvalda blvd. 1, Riga, LV 1010, Latvia

Phone: 371 67089923, 371 67089908,

Fax: 37167089908

e-mail: claudio.rochas@rtu.lv

Evita Garā, Claudio Rochas. Elektroierī̌̌u fonda modelēšana Latvijā un gaidī̌̌anas režīma zudumu noteikšana valstī

Jebkurai elektriskajai un elektroniskajai ierīcei var būt viens vai vairāki iekārtu režīmi. Aktīvais režīms, pasīvais vai aktīvais gaidīšanas režīms un izslēgts režīms. Gaidīšanas režīms visā pasaulē gadā sastāda vidēji no 200 - 400 TWh elektroenerǵijas patēriņa, katrā valstī tas ir atšķirīgs un svārstās vidēji no 6 līdz 13 \% no kopējā mājsaimniecību elektroenerǵijas patēriṇa, rezultātā rodas oglekḷa dioksīda emisijas, lai šo elektroenerǵiju saražotu, kas pasaules mērogā sastāda apmēram $1 \%$ no kopējām globālajām emisijām. Līdz šim Eiropas un pasaules valstis izstrādājušas dažādus politiskos instrumentus, lai šĩ režīma jaudu samazinātu līdz minimumam, tādēl viens no instrumentiem ir Eiropas Savienībā izstrāāātā ekodizaina direktīva, kas paredz, ka 2010. gadā, iekārtas nedrīkst patērēt vairāk kā 2 W gaidīšanas režīmā un $1 \mathrm{~W}$ izslēgtā režīmā, savukārt 2013. gadā šīs robežvērtības tiek samazinātas uz pusi, attiecīgi $1 \mathrm{~W}$ un $0,5 \mathrm{~W}$.

Esošo jauno iekārtu mērījumi Latvijā līdz šim ir apstiprinājuši, ka ne visas iekārtu kategorijas atbilst 2010. gada prasībām, savukārt, lai izpildītu 2013. gada noteiktās robežvērtības uz doto brīdi no jaunajām iekārtām, kas ienāk tirgūu šo prasību nespēj izpildīit $8 \%$ iekārtas izslēgtā režǐmā un 33 \% iekārtas gaidīšsanas režīmā. Galvenā mērka sasniegšanai tika noteikta vidējā Latvijas mājsaimniecība, tās elektroenerg̛ijas patēriṇš, izmaksas un saražotās oglekḷa dioksīda emisijas, lai noskaidrotu gaidīšanas režīma samazināšanas potenciālu, ko iespējams sasniegt, izpildot ekodizaina prasības. Nosakot visu Latvijas mājsaimniecību gaidīšanas režīma patērinu, tika noteikts, ka gaidīšanas režīma patērinš sastāda vidēji 8,8 \% no mājsaimniecību kopējā elektroenerǵijas patērina, kas ir 2 \% no kopējā Latvijas elektroenerǵijas patēriņa. Ekodizaina direktīvas prasību izpildes gadījumā gan jaudu, gan elektroenerğijas patēriņu, gan izmaksas un oglekḷa dioksīda emisijas iespējams samazināt no $69 \%$ līdz $74 \%$, kas samazinātu gaidīšanas režīma patēriṇu mājsaimniecībās no 8,8 \% līdz 2,7 \%, savukārt uz Latvijas kopējā elektroenerǵijas patēriņa fona, no $2 \%$ līdz $0,6 \%$.

Эвита Гара, Клаудио Роша. Моделирование фонда электроприборов в Латвии и определение потерь электроэнергии в режиме ожидания Любой прибор, потребляющий энергию, может работать в одном или нескольких режимах. Выделяют активный, пассивное или активное ожидания, и выключенный режимы работы приборов. Потребление энергии в режиме ожидания во всём мире составляет примерно $200-400$ TWh, в каждой стране этот объём разнится и может составлять от 6 до 13\% от общего потребления электроэнергии в быту. Чтобы произвести такое количество энергии, производится количество выбросов $\mathrm{CO}_{2}$, составляющее $1 \%$ от общего объёма мировых выбросов. До сегодняшнего дня страны Европы и всего мира разработали различные политические инструменты, способствующие снижению потребления энергии в этом режиме до минимума. Один из таких инструментов - Директива по экодизайну, предусматривающая снижение потребления энергии для приборов в режиме ожидания до 2 W и в выключенном режиме - до $1 \mathrm{~W}$ в 2010 году, и до $1 \mathrm{~W} 0,5 \mathrm{~W}$ соответственно в 2013.

Измерения, проведённые для существующих электроприборов в Латвии, подтвердили, что не все категории приборов соответствуют требованиям 2010 года, а среди тех приборов, которые только входят на рынок, требования 2013 года не смогут выполнить 8\% в выключенном режиме и 33\% - в режиме ожидания.

Для достижения главной цели - оценки потенциала снижения потребления в режиме ожидания, выполняя тербования директивы, было выведено среднее латвийской домашнее хозяйство, его энергопотребление, расходы и произведённые относительные выбросы углекислого газа. После определения потребления энергии в режиме ожидания для всех домашних хозяйств было установлено, что этот объём составляет в среднем 8.8\% от общего потребления электроэнергии в хозяйствах, что составляет $2 \%$ от общего потребления энергии в Латвии. В случае выполнения требований директивы снижение мощностей, потребления электроэнергии, расходов и выбросов может быть снижено с 69\% до 74\%, что снизит потребление электроэнергии в режиме ожидания в хозяйствах с 8,8\% до 2,7\%, а на уровне всей страны - с $2 \%$ до $0,6 \%$. 